\title{
Surviving Mass Extinctions Through Biomineralized DNA
}

\author{
Pau Turon, ${ }^{[a]}$ Jordi Puiggalí, ${ }^{[a]}$ Oscar Bertrán ${ }^{[b]}$, Carlos Alemán ${ }^{\star[a]}$
}

\begin{abstract}
Even in the worst of conditions, such as those which occurred during mass extinction events, life on Earth never totally stopped. Aggressive chemical and physical attacks able to sterilize or poison living organisms occurred repeatedly. Surprisingly, DNA was not degraded, denatured or modified to the point of losing the capability of transferring the genetic information to the next generations. After the events of mass extinction life was able to survive and thrive. DNA was passed on despite being an extremely fragile biomolecule. The potential implications of hydroxyapatite protection of DNA are discussed including how DNA acts as a template for HAp formation, how cell death can trigger biomineralizatoin, and how DNA can be successfully released from HAp when the conditions are favourable for life.
\end{abstract}

\section{Introduction}

The importance of calcification processes, such as fossilization, for the understanding of the development of life on Earth is well documented. ${ }^{[1-3]}$ Biomineralization of desoxirribonucleic acid (DNA) has recently been studied at atomic level ${ }^{[4-7]}$ revealing that DNA acts as a template for hydroxyapatite (HAp) crystallization (Figure 1). As a consequence, HAp adsorbs or encapsulates DNA and thus protects the biomolecule from external attacks. ${ }^{[8]}$ In this paper, we refer to this particle as hydroxyolite.

Periods of Mass Extinctions are the most aggressive events that life has faced. It is worth reviewing them from the perspective of DNA-HAp interaction and the synergistic effect against aggressive environmental conditions. This is the aim of this work, which focuses on the physical, chemical and biological

[a] Mr. Pau Turon

Department of Research and Development, Regulatory Affairs and Quality Management. B. Braun Surgical, S.A. Ctra. de Terrassa, 121. 08191. Rubí. Barcelona. Spain. E-mail:pau.turon@bbraun.com

Prof. Dr. Jordi. Puiggalí

Departament d'Enginyeria Química, E.T.S. d'Enginyeria Industrial de Barcelona. Universitat Politècnica de Catalunya, Diagonal 647, 08028 Barcelona. Center for Research in Nano-Engineering, Universitat Politècnica de Catalunya, Campus Sud, Edifici C', C/Pasqual i Vila s/n, Barcelona E-08028, Spain.

E-mail: Jordi.puiggalí@upc.edu

Prof. Dr. Carlos Alemán

Departament d'Enginyeria Química, E.T.S. d'Enginyeria Industrial de Barcelona. Universitat Politècnica de Catalunya, Diagonal 647 , 08028 Barcelona. Center for Research in Nano-Engineering, Universitat Politècnica de Catalunya, Campus Sud, Edifici C', C/Pasqual i Vila s/n, Barcelona E-08028, Spain. E-mail: carlos.aleman@upc.edu

[b] Dr. Oscar Bertran

Departament de Física Aplicada, EEI, Universitat Politècnica de Catalunya, Av. Pla de la Massa, 8, 08700 Igualada, Spain. E-mail:oscar.bertran@upc.edu implications of the biomineralization of DNA for the persistence of life after aggressive events (Figure 2). From a simplified perspective a cell might be considered to be a soft organic DNA protective capsule with all the functions for sustaining active life. In other words, it is a perfect mechanism for replicating and transmitting the genetic code to the next generation. The proposed existence of the Universal Common Ancestry ${ }^{[9]}$ (UCA), the grandfather of all living organisms, reinforces the robustness of DNA as a successful biochemical infrastructure that has supported life through time. Since the time of UCA, and probably even earlier, the requirement of collecting, keeping and transmitting information essential for life has been fulfilled using an extremely simple system based on a double pair of nitrogen bases bonded to a sugar phosphate backbone. The main hurdle for this fine tuned and fragile system is that it can easily be stopped by mild physical or chemical aggressions. Conversely, an inactive inorganic long-lasting shield of calcium phosphate seems to be the opposite alternative to protect DNA. Are both approaches linked? From our point of view, the biomineralization process connects both, making them complementary, thus explaining the resilience of the DNA life based system.

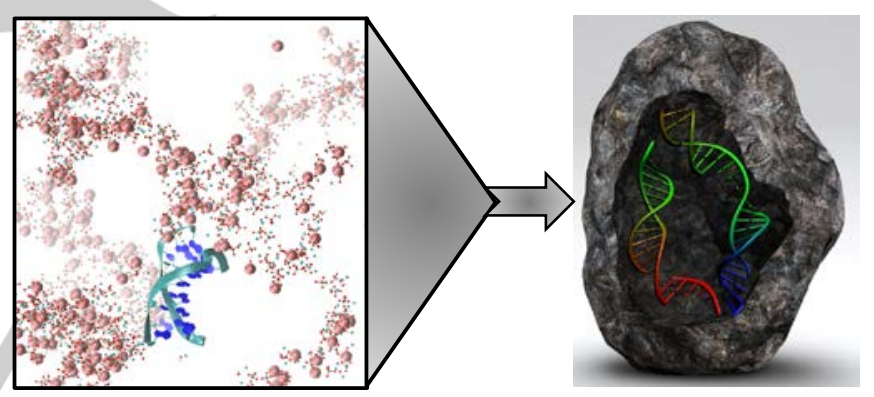

Figure 1. Schematic description of the hydroxyapatite encapsulation of DNA (hydroxyolite). The biomineralization process of DNA has been not only observed experimentally but also described at the molecular level using atomistic computer simulations. ${ }^{[4,7]}$

Here we explore the synergies for life development based on bioinorganic interactions between DNA and HAp and the role of HAp in biochemical reactions. We consider cell death as a trigger of biomineralization process and the processes of reintroduction of the biomineralized DNA in the life cycle, drawing conclusions on how DNA could pass on the mass extinction events.

\section{DNA - HAp interactions}

Extinction events have occurred several times since life began. They had catastrophic consequences for living organisms, significantly reducing the number of living species (Figure 2). The "Big Five", Ordovician (ca. 443 Myr), Devonian (ca. 359 Myr), Permian (ca. $251 \mathrm{Myr}$ ), Triassic (ca. $200 \mathrm{Myr}$ ) and Cretaceous (ca. $65 \mathrm{Myr}$ ), were remarkably intense (> $75 \%$ 
reduction of species). ${ }^{[10]}$ Surprisingly, DNA (the only mechanism for transferring the genetic code to next generations) was able to be passed on without being deactivated.

Current theories on the origins of life propose an initial RNA world $^{[11]}$ and posterior development of DNA, suggesting that both RNA and DNA biopolymers were likely to be synthesized through heterogeneous catalysis on mineral surfaces such as montmorillonite. ${ }^{[12,13]}$ The DNA capacity of interaction with several inorganic substrates (not only silicates) is remarkable. ${ }^{[14]}$ We highlight HAp for its strong capacity of interaction with biomolecules. DNA acts as a template of HAp in physiological conditions. Additionally, we note that the nature of DNA-HAp interaction on the crystal surface depends on the exposed face of the crystal (Figure 3 ) ${ }^{[8]}$ The binding on (001) face, the most favorable, maintains the B-DNA double helix conformation Conversely, the interaction on face (010) terminated with $\mathrm{Ca}^{2+}$, $\mathrm{OH}^{-}$and $\mathrm{PO}_{4}{ }^{3-}$, denoted $\left(010 ; \mathrm{Ca}^{2+}-\mathrm{OH}^{-}\right)$provokes DNA structural deformations and rejection. Finally, the binding on the side of the (010) terminated with $\mathrm{Ca}^{2+}$ and $\mathrm{PO}_{4}{ }^{3-}$ ions, $(010$; $\mathrm{Ca}^{2+}$ ) shows very strong attractive interactions, which are intense enough to distort the double helix structure and crush the molecule towards the surface. Additionally, considering the morphological aspects of HAp, we observed that amorphous nanospheres and fusiform rods, synthesized under controlled reaction conditions, showed enhanced protection against the aggression of external factors like enzymatic degradation by DNAse compared to sheet crystals. ${ }^{[8]}$

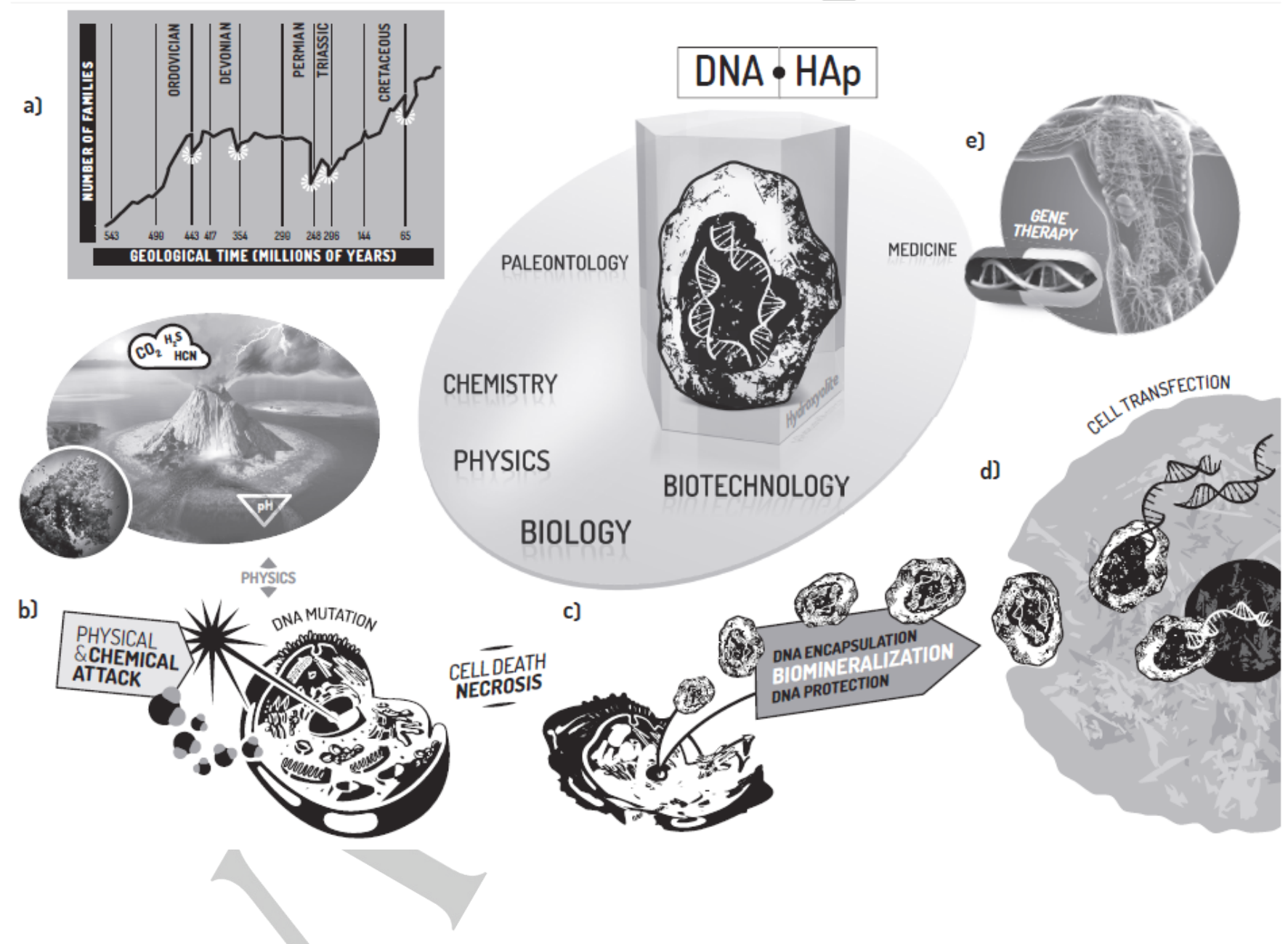

Figure 2. Proposed HAp-DNA (hydroxyolite) connections to multiple scientific disciplines. a) Paleontology, Number of families decrease during the Big Five mass extinction events when hydroxyolites are expected to be spontaneously formed. Graphic adapted with permission from Erwin, D.H. et al. 1987. A comparative study of diversification events: the early Paleozoic vs. the Mesozoic, Evolution 37, 1177-1186. Copyright 1987, Wiley. b) Chemistry and Physics: Gases expulsed by volcanoes caused cell death acting as toxins or causing death by hypoxia. Radiation or temperature variations also caused cell death. c) Biology: Cells damaged or killed undergo cell death processes, like necrosis. The subsequent DNA encapsulation depends on the availability of $\mathrm{Ca}^{2+}$ and $\mathrm{PO}_{4}{ }^{3-}$. Encapsulated DNA remains functional for a long time. d) Biotechnology, cell transfection by encapsulated DNA in HAp is likely to reintroduce DNA in the life cycle of a cell. e) Medicine, gene therapy is based on the introduction of a gene into the cell with the objective of healing it. The use of HAp for encapsulating DNA is possible but the rate of success is low and the process is not efficient. 
Travelling back to the very origin of life it is worth noting that the finding of the first abiotic carbon was reported in 1996 by Mojzsis and coworkers ${ }^{[15]}$ when they identified $a{ }^{13} \mathrm{C}$-depleted microscopic graphite inclusion inside apatite dated 3,830 million years old in Akilia (Greenland). It was interpreted as a possible biomarker indicating the early connection between apatites and life. Recently, well-preserved soft tissue in fragments of demineralized cortical and/or medullary bone from the Cretaceous to the present day have been reported, and proteins have been detected in dinosaur bone micro structures. ${ }^{[16]}$ The strong relationship between calcified structures and biopolymers can still be found in current organisms. The role of HAp as catalyst of many organic basic reactions is not a minor one ${ }^{[17-19]}$ and of special interest are reactions where chemistry of surfaces is involved. ${ }^{[20]}$ As an example, essential biochemical reactions take place around mineralized calcium phosphate scaffolds such as bones (i.e. production of mesenchymal stem cells and platelets inside bone marrow). ${ }^{[21]}$ Enhancing its role for homeostasis HAp incorporates fixed quantities of $\mathrm{Mg}^{2+}$ in its lattice, ${ }^{[22]}$ that allows regulation of available $\mathrm{Mg}^{2+}$ which remains free to react in basic metabolic reactions as cell respiratory systems. Additionally, $\mathrm{Mg}^{2+}$ is able to stabilize DNA modulating its structure and dynamics. ${ }^{[23]}$ Misbalances of $\mathrm{Mg}^{2+}$ are related to several diseases.

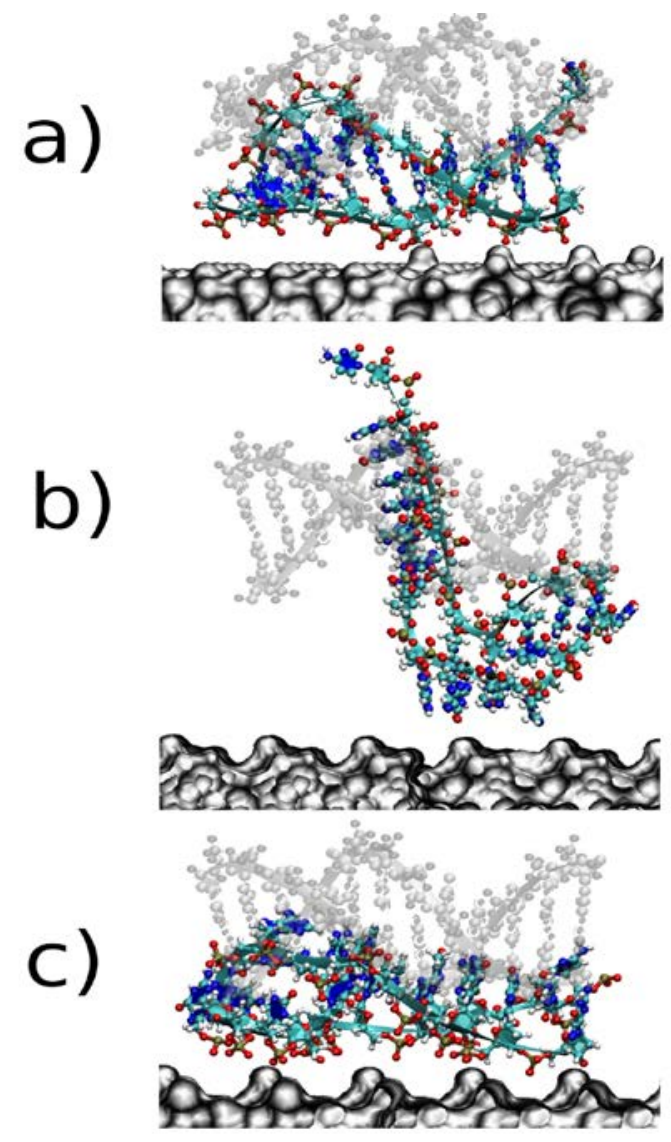

Figure 3. Interaction of DNA with three different HAp surfaces (in grey the initial state, in colour the final state): a) DNA is attracted to the surface of face (001) and DNA double helix is not distorted, b) DNA is distorted and repelled when interacts with the face $\left(010 ; \mathrm{Ca}^{2+}-\mathrm{OH}^{-}\right)$terminated with $\mathrm{Ca}^{2+}, \mathrm{OH}^{-}$and $\left.\mathrm{PO}_{4}{ }^{3-}, \mathrm{c}\right)$ DNA is strongly attracted to the side $\left(010 ; \mathrm{Ca}^{2+}\right)$ causing double helix distortion and crushing the molecule towards the surface.

\section{Triggers for biomineralization}

DNA is a biopolymer that is easily affected and degraded by chemicals $^{[24]}$ or physical treatments (radiation) ${ }^{[25]}$, becoming mutated or denatured. The fragility of the DNA supporting life systems becomes evident when unprotected cells are exposed to an excess of solar ultraviolet radiation: they become damaged, mutated or carcinogenic ${ }^{[26]}$. The question of how DNA was able to overcome the aggressive condition of mass extinction events remains open ${ }^{[9]}$. Reviewing the hypotheses of how mass extinction events took place we observe that during the Ordovician period repeated glacial episodes occurred. The uplift and weathering of the Appalachians affected the atmospheric and ocean chemistry, including the sequestration of $\mathrm{CO}_{2}$. Additionally, at the end of the period, a gamma ray burst caused a severe depletion of the ozone layer and the Earth received an intense solar ultraviolet radiation ${ }^{[27]}$ that sterilized the earth's crust. The Devonian period was affected by a global cooling, weathering and drawdown of global $\mathrm{CO}_{2}$ with periods of anoxia. The Permian extinction event was determined by Siberian volcanic activity that lead to elevated $\mathrm{H}_{2} \mathrm{~S}$ and $\mathrm{CO}_{2}$ concentrations which poisoned both marine and terrestrial ecosystems in conjunction with a global temperature increase. As a consequence the oceans become more acid and marine waters anoxic. The Triassic registered magmatic activity and elevated atmospheric $\mathrm{CO}_{2}$ levels with an increase in global temperatures which resulted in a calcification crisis in the world's oceans. ${ }^{[28]}$ Finally, the Cretaceous period was characterized by a rapid cooling due to a bolide impact that provoked a global cataclysm. How could DNA survive as a coherent molecule keeping the ability of transmitting life despite these repeated aggressions? A plausible answer is that DNA was encapsulated or protected by HAp.

\section{Cell death}

When cells are affected by external aggressions they might undergo cell death, most likely through necrosis ${ }^{[29-31]}$ but other mechanisms, such as apoptosis, necroptosis or pyroptosis can not be discounted ${ }^{[32]}$. Here we use the explanation of necrosis as representative and most likely process under these conditions. Necrotic status causes the cell membrane to collapse and release the cell content into the surrounding environment (usually the extracellular matrix). Several chemical mechanisms can trigger necrosis such as calcium misbalance, hypoxia, ATP depletion and excess of Reacting Oxygen Substances (ROS). Necrosis can happen when cells suffer freezing and defreezing cycles or DNA is damaged by ultraviolet or gamma radiation. All of them can cause the uncontrolled release of DNA from the nucleus. When DNA released in combination with calcium $\left(\mathrm{Ca}^{2+}\right)$ and phosphate $\left(\mathrm{PO}_{4}{ }^{3-}\right)$ available into the cell, it can act as a calcifying template $\mathrm{e}^{[7]}$ and the biomineralization process will end up in a necrotic calcification ${ }^{[33]}$. Usually calcium homeostasis system prevents this from happening. Calcium homeostatic systems appeared very early in the history of life as a survival mechanism preventing $\mathrm{Ca}^{2+}$ mediated cell damage. An excess of cytosolic calcium is incompatible with life because initiates the precipitation of phosphates, starts the aggregation of proteins 
and nucleic acids and finally affects the integrity of lipid membranes. ${ }^{[34]}$ Calcium, an extremely versatile ion, participates in several relevant cell processes like fertilization, embryonic pattern formation, cell differentiation and cell death. Calcium concentration usually is around $100 \mathrm{nM}$ when the cell is at rest but raises to $1000 \mathrm{nM}$ when activated. Higher concentrations are cytotoxic. The availability of calcium in a cell is extremely regulated and depends on several interconnected factors. ${ }^{[35,36]}$ Among them, we highlight both the role of the endoplasmic reticulum (ER), as the main store of calcium (total $\mathrm{Ca}^{2+}$ in $\mathrm{ER}$ is about $2 \mathrm{mmol} / \mathrm{L}$ but free $\mathrm{Ca}^{2+}$ in $\mathrm{ER}$ is about $\left.50-500 \mu \mathrm{mol} / \mathrm{L}\right),{ }^{[37]}$ and the role of mitochondria due to their ability to rebalance the calcium concentration in the cytosol. The membrane systems of the endoplasmic reticulum (ER) hold the stores of calcium. The release is controlled by various channels (i.e. inositol-1,4,5trisphosphate receptor and ryanodine receptor are the most studied) but it is interesting to note that the principal activator of these channels is $\mathrm{Ca}^{2+}$ itself and this autocatalytic process is central to the mechanism of $\mathrm{Ca}^{2+}$ signaling. ${ }^{[35]}$ On the other hand mitochondria are able to capture high concentrations of calcium ions from cytosol by allowing the precipitation of HAp inside of them. ${ }^{[38,39]}$ Such reservoirs of calcium and phosphate are mobilized when mitochondria are damaged or cells are necrosed ${ }^{[40]}$. Additionally, mitochondria are able to release polyphosphates, ${ }^{[41,42]}$ archaic polymers present in all living species from Archae to Eukaryotes, to the cytosol, where they are then converted by hydrolysis to additional phosphates. ${ }^{[43]}$ Polyphosphates might also be attracted to the HAp surface ${ }^{[44]}$ to specific sites recently defined at atomic level, creating a polymeric outer layer on the HAp (Figure 4).
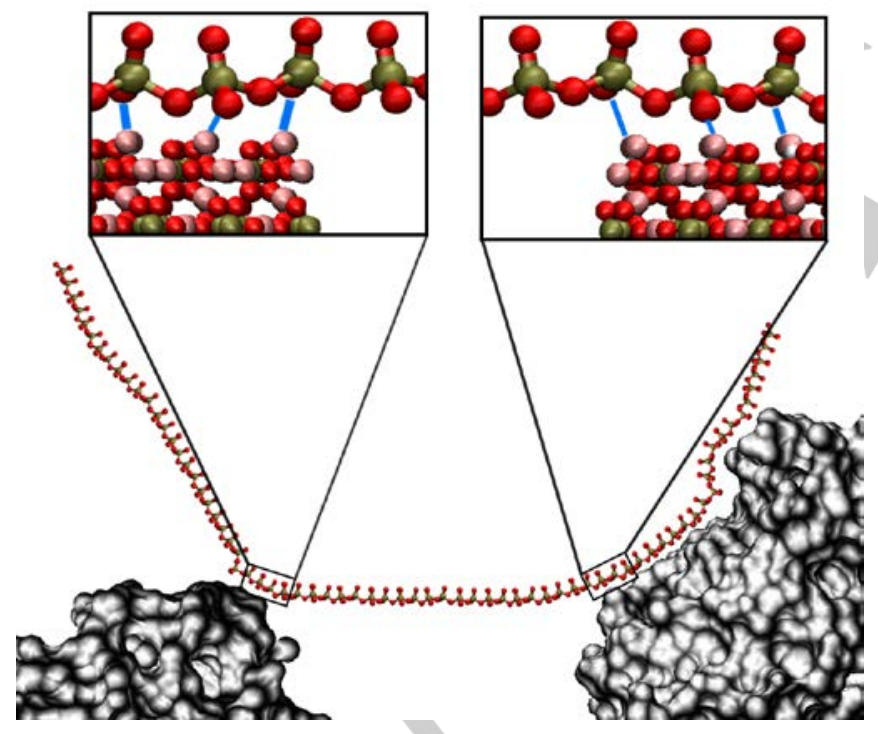

Figure 4. Polyphosphate binding to HAp surface

The combination of both endoplasmic reticulum and mitochondria malfunctions due to external aggressions, might provide the source of both calcium and phosphate for HAp-DNA particle formation, particularly taking into consideration that mitochondria have their own mtDNA that usually become mutated when cells are getting older ${ }^{[45]}$ Dead cells will not be viable but DNA remains totally or partially protected from the environmental aggression when adsorbed or encapsulated Transferring this fact to the mass extinction perspective we can expect that when cells were stressed by the aggressive environmental conditions, a significant part of them were damaged or killed. Thus a large quantity of HAp-DNA nanoparticles were likely to be formed preserving DNA from further attacks. In parallel, we recognize that other mechanisms of adaptation to environmental stressing conditions were developed during the recovery after each mass extinction event. $^{[46]}$

\section{Resilience of HAp}

The resilience of the hydroxyolite particles is also due to several additional intrinsic features of HAp that reinforce the probability of surviving the environmental attack unaltered, or with minor secondary effects. HAp is able to adsorb contaminants like formaldehyde ${ }^{[47]}$ whereas it enhances their further catalytic oxidation ${ }^{[18]}$ at room temperature. A high adsorption of cyanide ions by HAp is reported to be a promising air purification system. ${ }^{[48]}$ Formaldehyde and cyanide are interesting because they are considered to be substances released by volcano eruptions into the atmosphere, and they are molecules whose involvement is necessary in starting life reactions. HAp can be activated by strong chemical conditions that modify its surface texture giving high performance properties. ${ }^{[49]}$ Furthermore, HAp performs well under high radiation doses ( $<30 \mathrm{kGy}$ ), similar to what is commonly used to sterilize medical devices, as HAp is able to protect organic polymers like collagen without losing their biocompatibility properties. ${ }^{[50]}$ Interestingly, the radiation might generate active oxygen radicals on the HAp surface, such as ${ }^{\circ} \mathrm{OH}, \mathrm{O}_{2}{ }^{--}$(UV) or $\mathrm{CO}_{2}(\mathrm{Y})$, which could lead to the enhancement of chemical reactions including DNA mutations. ${ }^{[51,52]}$ Ionized electrons by radiation remain trapped in the HAp crystalline structure, which is a useful feature as a bone dosimeter for recording the radiation history of skeleton or fossil dating. ${ }^{[53]}$ Finally, HAp is able to retain in its structure a wide variety of heavy metal ions which could damage DNA such as lead, copper, tin, uranium, aluminum and nickel. ${ }^{[54,55]}$

HAp is not the only candidate for DNA protection: for example, silicates share some structural characteristics with apatite which would be compatible with DNA interactions. ${ }^{[56,57]}$ Montmorillonite, illite, and kaolinite represent clay minerals that are able to protect DNA from nucleases during natural bacterial genetic transformation ${ }^{[58,59]}$ and they are also useful for gene delivery as silica nanoparticles, but their slow degradation rate decreases efficiency ${ }^{[60,61]}$ compared to HAp.

\section{Reintroducing DNA into the life cycle}

The potential impact of a hydroxyolite, a nanometric particle, for life continuation is not negligible (Figure 2). Since the 1970s calcium phosphate has been well known as a non-viral carrier used for gene therapy. Particles with transfection capability are in the range of $20-200 \mathrm{~nm}^{[43]}$ Hydroxyolites are capable of introducing plasmids into the nucleus ${ }^{[62,63]}$ where the plasmid recombines with cell DNA. For some decades HAp transfection was almost abandoned due to its low transfection efficiency but 
recently it has become more attractive, as HAp is highly biocompatible and has less side effects compared to other transfecting agents, like viral vectors. ${ }^{[64,65]}$

The hydroxyolite capsules, once formed, can stay "on hold" and remain passive for years until the aggressive environment relaxes or totally disappears. After clearance, the encapsulated DNA could have the option of being reintroduced again into the life cycle by two main mechanisms: i) redissolution of the particle or ii) uptake by a living cell. First, several solubility factors affect $\mathrm{HAp}:{ }^{[66]}$ method of preparation, crystallinity, density and extent of ionic substitutions into the apatite lattice. Particularly interesting is the carbonate substitution extensively observed in living organisms, as it increases the solubility. Fluoride substitution observed in enamel decreases solubility. Finally, highly crystalline particles usually result in very insoluble structures, whilst particles which are poorly in crystalline have higher relative solubilities. ${ }^{[67,68]}$ The redissolution process by pure acid attack $(\mathrm{HCl})$ is 10 fold easier when sodium $\left(\mathrm{Na}^{+}\right)$and chloride $\left(\mathrm{Cl}^{-}\right)$are present in the aqueous solution at low concentrations (in the milliMolar range). ${ }^{[69]}$ The molecular mechanism that drives solubility remains unclear despite the efforts for clarifying it and several models proposed in the literature. ${ }^{[0,71]}$

Secondly, eukaryotic cells can internalize particles bigger than $10 \mathrm{~nm}$ through the endocytic pathways including phagocytosis, macropinocytosis, clathrin-mediated, endocytosis and nonclathrin-mediated endocytosis such as internalization via caveolae. ${ }^{[72]}$ As representative mechanisms for HAp internalization we mention endocytosis and macropinocytosis. In the first, the cell membrane invaginates before uptaking the nanoparticle. In the second, macropinocytosis, the particle first goes to the endosomes and then to the lysosomes, dissolving under the acidic conditions. ${ }^{[73]}$ The combination of cell uptake and redissolution is specially relevant during the event of transfection when the particle releases DNA to the nucleus or cytosol. The buffering properties of HAp are important for protecting DNA against DNAse degradation during this process. ${ }^{[74]}$ Additionally, it is worth mentioning that it is not difficult to release DNA from HAp. Only a slight increase in temperature or a decrease in $\mathrm{pH}$ is necessary to discharge DNA from $\mathrm{HAp}^{[75]}$. An increase in ionic strength, phosphate gradients or other solvents mimicking the chromatographic conditions used for DNA separation in HAp columns also result in DNA release from HAp. ${ }^{[76,77]}$

Summarizing, DNA is protected from the environment after cell death but is not isolated forever. When favorable life conditions reappear, hydroxyolite particles have the ability of delivering DNA to a new cell, promoting a recombination of genetic code and potentially starting diversification, as usually observed after the event of mass extinction (Figure 2). ${ }^{[78]}$ Single or double stranded RNA have the same potential of templating HAp and becoming encapsulated or adsorbed as an hydroxyolite ${ }^{[1]}$ without losing functionality that will be essential for restarting life.

\section{Concluding remarks}

This work provides an example of how chemical concepts extracted from both laboratory and computer simulation experiments can be extended to very diverse and relatively far fields of science, such as Evolution, to correlate and explain important observations about Life itself.
It is highly likely that life has evolved up to now using several mechanisms to protect the information encoded in DNA. HAp is currently intensively interlinked with biochemical processes. All of these processes run at physiological conditions of temperature and $\mathrm{pH}$. Its unique properties of accepting different ions on its flexible lattice, gases on its surfaces and biomolecules on its interior makes it likely that HAp played an outstanding role during the relevant life events on Earth.

Environmental stressing conditions are expected to damage DNA. At a first glance, looking at its lability, fragility and instability DNA is not expected to survive unscathed after being exposed to damaging conditions with unfavorable circumstances. But the evidence of life today confirms that even the most aggressive events which occurred in the past could not stop live thriving; therefore, despite the fact that DNA was probably modified or mutated during the events of mass extinction, it was not denatured or destroyed. Its resilience is remarkable, thus the hypothesis of a combination of DNA with an inorganic shell of HAp gains credibility. Hydroxyolites (DNA-HAp nanoparticles) are thermodynamically favored. HAp is easy to redissolve and able to carry the encoded information without modifying it. The power of these particles for transmitting information to living cells explains that HAp has been used as a gene therapy vector. Only its low efficiency prevents it from being the most used mechanism for transfecting cells. Thus, its ability to protect and transmit DNA probably made the difference throughout the mass extinction events for the survival of life. This hypothesis is reinforced by the biomineralization process observed when a cell dies under certain stressing conditions. After a while, a necrotic calcification appears that frequently is no more than a particle containing DNA (on its surface or in its interior) trying to protect the invaluable information for life. It can be considered to be the first survival mechanism of the cell.

Considering all the reviewed arguments, the potential of hydroxyolites to help us understand the evolution of life remains an interesting field to be explored in depth. Further research is necessary to confirm the process of DNA encapsulation after cell death, how and where DNA remains preserved and how the reintroduction of DNA into the life cycle really works.

Watson and Crick $^{[79]}$ realized the importance of the double helix for life, thus changing the understanding of medicine, diseases, genetics and the origin of life. From our perspective, the DNA-HAp particle has to be understood as a molecule in its mould. HAp has the potential to be the Troyan horse that protected and hid DNA through mass extinction events and this throughout the whole History of life on earth.

\section{Acknowledgements}

This work was supported by B. Braun Surgical S.A. through a joint research agreement with UPC, MINECO-FEDER funds (MAT2012-34498 and MAT2012-36205). This work is integrated within a wider research project supported by B. Braun Surgical S.A., UPC, Institut de Ciencies Fotòniques (ICFO), and the Institut Català de la Salut (ICS) through the H. U. Germans Trias i Pujol and I.R. Vall d'Hebron. Special thanks to Dr. Joan Francesc Julián, Dr. Jordi Navinés, Dr. Mariantònia. Arbós, Dr. Maite Quiles, Dr. Susana Santos, Dr. Johann Osmond, Prof. Dr. Romain Quidant, Ms. Eunice Rodríguez, Ms. Elisabet Rodríguez 
and Mr. Joan Marc Turon for their valuable contributions in the revision of this document and thanks to Mr. Antoni Lacasa for their contribution to the design of Graphical Abstract and Figure 1 and to Mr. Andrés Rodríguez (Genialum) for preparing Figure 2. We also thank two anonymous referees for their valuable contributions.

Keywords: Biomineralization • DNA • Hydroxyapatite • Mass extinction · Hydroxyolite.

[1] P.C.J. Donoghue, M.J. Benton, Trends Ecol. Evol. 2007, 22, 424-431.

[2] A.H. Knoll, Rev. Mineral. Geochem. 2003, 54, 329-356.

[3] S.M. Porter, Science 2007, 316, 1302-1304.

[4] G. Revilla-López, J. Casanovas, O. Bertran, P. Turon, J. Puiggalí and C. Alemán, Biointerphases 2013, 8, 10.

[5] T. Takeshita, Y. Matsuura, S. Arakawa and M. Okamoto. Langmuir 2013, 29, 11975-11981.

[6] K. B. Vasconcellos, S. M. McHugh, K. J. Dapsis, A. R. Petty, A. E. Gerdon, J. Nanopart. Res. 2013, 15, 1942. 1-11.

[7] O. Bertran, L. J. del Valle, G. Revilla-López, G. Chaves, L. Cardus, M. T. Casas, J. Casanovas, P. Turon, J. Puiggalí, C. Alemán, Dalton Trans., 2014, 43, 317-327

[8] L.J. del Valle, O. Bertran, G. Chaves, G. Revilla-López, M. Rivas, M. T. Casas, J. Casanovas, P. Turon, J. Puiggalí, C. Alemán, J. Mater. Chem. B 2014, 2, 6953-6966.

[9] D.L. Theobald, Nature 2010, 465, 219-222.

[10] A.D. Barnosky, N. Matzke, S. Tomiya, G.O.U. Wogan, B. Swartz, T.B. Quental, C. Marshall, J.L. McGuire, E.L. Lindsey, K.C. Maguire, B. Mersey, E. A. Ferrer, Nature 2011, 471, 51-57

[11] W. Gilbert, Nature 1986, 319, 618-618.

[12] P.C. Joshi, M.F. Aldersley, J.P. Ferris, Biochem. Biophys. Res. Commun. 2011, 413, 594-598.

[13] G. Ertem, J.P. Ferris, J.P., Nature 1996, 379, 238-240

[14] H.J. Cleaves II, E. Crapster-Pregont, C.M. Jonsson, C.L. Jonsson, D.A Sverjensky, R.A. Hazen, Chemosphere 2011, 83, 1560-1567.

[15] S.A. Mojzsis, G. Arrhenius, K.D. McKeegan, K.D. Harrison, T.M, A.P. Nutman, C.R.L. Friend, Nature 1996, 384, 55-59.

[16] M.H. Schweitzer, J.L. Wittmeyer, J.R. Horner, Bone 2013, 52, 414-423.

[17] L.E. Orgel, Crit. Rev. Biochem. Mol. Biol. 2004, 39, 99-123.

[18] J. Xu, T. White, P. Li, C. He, Y. Han, J. Am. Chem. Soc. 2010, 132, 13172-13173.

[19] S.A. Benner, H-J Kim, M.A. Carrigan, Acc. Chem. Res. 2012, 45, 2025 2034

[20] P. Ducheyne, Q. Qiu, Biomaterials 1999, 20, 2287-2303.

[21] P. Bianco, M. Riminucci, S. Gronthos, P. Gehron, Stem Cells, 2001, 19 180-192.

[22] O. Bertran, L.J. del Valle, G. Revilla-López, M.Rivas, G. Chaves, M.T. Casas, J. Casanovas, P. Turon, J. Puiggalí, C. Alemán, Chem. Eur. J. 2015, 21, 2537-2546

[23] M. Guéroult, O. Boittin, O. Mauffret, C. Etchebest, B. Hartmann, PLoS ONE 2012, 7, e41704

[24] K. Cheung-Ong, G. Giaever, C. Nislow, Chem. Biol. 2013, 20, 649-659.

[25] K. Suzuki, M. Ojima, S. Kodama, M. Watanabe, Oncogene 2003, 22, 6988-6993.

[26] J. Cadeta, E. Sageb, T. Doukia. Mutat. Res. 2005, 571, 3-17.

[27] A.L. Melott, B.S. Lieberman, C.M. Laird, L.D. Martin, M.V. Medvedev, B.C. Thomas, J.K. Cannizzo, N. Gehrels, C.H. Jackman Int. J. Astrobiology 2004, 3, 55-61.

[28] J.L. Hinojosa, S.T. Brown, J. Chen, J.D. DePaolo, A. Paytan, S-z. Shen, J.L. Payne. Geology 2012, 40, 743-746.

[29] S.Y. Proskuryakov, V.L. Gabai. Curr. Pharm. Des. 2010, 16, 56-68

[30] S.Y. Proskuryakov, A.G. Konoplyannikov, V.L. Gabai, Exp. Cell. Res. 2003, 283, 1-16.

[31] R.S. Hotchkiss, A. Strasser, J.E. McDunn, P.E. Swanson, New Engl. J. Med. 2009, 16, 1570- 1583

[32] S.W.G. Tait, G. Ichim, D.R. Green, J. Cell Sci. 2014, 127, 2135-2144
[33] F. Kalantari, D. Miao, A. Emadali, G.N. Tzimas, D. Goltzman, H. Vali, E. Chevet, P. Auguste, Mod. Pathol. 2007, 20, 357-366.

[34] R.M. Case, D. Eisner, A. Gurney, O. Jones, S. Muallemd, A Verkhratsky, Cell Calcium 2007, 42, 345-350.

[35] M.J. Berridge, P. Lipp, M.D. Bootman, Nature Rev. Mol. Cell Biol. 2000, 1, 11-21.

[36] D.E. Clapham, Cell 2007, 131, 1047- 1058

[37] H. Coe, M. Michalak, Gen. Physiol. Biophys. 2009, 28, 96-103.

[38] L. Contreras, I. Drago, E. Zampese, T. Pozzan, Biochim. Biophys. Acta 2010, 1797, 607-618.

[39] J.W. Greenawalt, C.S. Rossi, A.L. Lehninger, J. Cell Biol. 1964, 23, 21 38.

[40] R. Rizzuto, D. De Stefani, A. Raffaello, C. Mammucari, Nat. Rev. Mol. Cell Biol. 2012, 13, 566-578.

[41] S. Omelon, J. Georgiou, Z.J. Henneman, L.M. Wise, B. Sukhu, T. Hunt C. Wynnyckyj, D. Holmyard, R. Bielecki, M.D. Grynpas. PLoS ONE 2009, 4, e5634.

[42] K. Seidlmayer, M.R. Gomez-Garcia, L.A. Blatter, E. Pavlov, E.N Dedkova, J. Gen. Physiol. 2012, 139, 321-331.

[43] X. Cao, W. Deng, Y. Wei, W. Su, Y. Yang, Y. Wei, J. Yu, X. Xu, Int. J. Nanomedicine 2011, 6, 3335-3349.

[44] M. Rivas, J. Casanovas, L.J. del Valle, O. Bertran, G. Revilla-López, P. Turon, J. Puiggalí, C. Alemán, Dalton Trans. 2015, 44, 9980-9981.

[45] H-R. Kim, S.J. Won, C. Fabian, M. Kang, M. Szardenings, M-G. Shin Ann. Lab. Med. 2015, 35, 1-14.

[46] D.H. Erwin, Trends Ecol. Evol. 1998, 13, 344-349.

[47] T. Kawai, C. Ohtsuki, M. Kamitakahara, M. Tanihara, T. Miyazaki, Y. Sakaguchi, S. Konagaya, Environ. Sci. Technol. 2006, 40, 4281-4285.

[48] J.R. Parga, J.L. Valenzuela, V. Vázquez, M. Rodríguez, H. Moreno, Mater. Sci. Appl. 2013, 4, 231-237.

[49] U. Iriarte-Velasco, J.L. Ayastuy, L. Zudaire, I. Sierra, Chem. Eng. J. 2014, 251, 217-227.

[50] Y. Kawasaki, S. Sotome, T. Yoshii, I. Torigoe, H. Maehara, Y. Sugata M. Hirano, N. Mochizuki, K. Shinomiya, A. Okawa, J. Biomed. Mater Res. B Appl. Biomater. 2009, 92, 161-167.

[51] S.S. Ishchenko, I.P. Vorona, S.M. Okulov, N.P. Baran, V.V. Rudko Radiat. Meas. 2011, 46, 37-39.

[52] H. Nishikawa, Mater. Lett. 2003, 58, 14-16.

[53] S.L. Breentt, J.J. Battistat, Phys. Med. Biol. 1995, 40, 2065-2077.

[54] A. Aklil, M. Mouflihb, S. Sebti, J. Hazard. Mater. 2004, A112, 183-190.

[55] J. Seaman, J.C. Arey, J.S.; P.M. Bertsch, J. Environ. Qual. 30, 460-469.

[56] A.E. Porter, C.M. Botelho, M.A. Lopes, J.D. Santos, S.M. Best, W Bonfield, J. Biomed. Mater. Res. 2004, A 69, 670-679.

[57] A.E. Portera, N. Patela, J.N. Skepperb, S.M. Besta, W. Bonfielda Biomaterials 2003, 24, 4609-4620.

[58] M. Kawase, Y. Hayashi, F. Kinoshita, E. Yamato, J-i. Miyazaki, J. Yamakawa, T. Ishida, M. Tamura, K. Yagi, Biol. Pharm. Bull. 2004, 27, 2049-2051.

[59] S.A.E. Blum, M.G. Lorentz, W. Wackernagel, Syst. Appl. Microbiol 1997, 20, 513-521.

[60] L. Tang, J. Cheng, J., Nano Today 2013, 8, 290-312.

[61] S-H. Wu, Y. Hung, C-Y. Mou, Chem. Commun. 2011, 47, 9972-9985.

[62] V.V. Sokolova, I. Radtkeb, R. Heumannb, M. Epplea, Biomaterials 2006 27, 3147-3153.

[63] M. Motskin, D.M. Wright, K. Muller, N. Kyle, T.G. Gard, A.E. Porter, J.N. Skepper, Biomaterials 2009, 30, 3307-3317.

[64] E.H. Chowdhury, T. Akaike, Int. J. Nanomed. 2007, 2, 101-106.

[65] R.G. Crystal, Science 1995, 270,404-410.

[66] M.T. Fulmer, I.C. Ison, C.R. Hankermayer, B.R. Constantz, J.Ross Biomaterials 2002, 23, 751-755.

[67] Q. Liu, Z. Chen, H. Pan, B.W. Darvell, Ceram. Int. 2014, 40, 2751-2761.

[68] H. Pan, B.W. Darvell, Cryst. Growth Des. 2010, 10, 845-850.

[69] C.R. Hankermeyer, K.L. Ohashi, D.C. Delaney, J. Ross, B.R. Constantz, Biomaterials 2002, 23, 743-750.

[70] S.V. Dorozhkin, World J. Methodol. 2012, 26, 1-17.

[71] L. Wang, G.H. Nancollas, Chem. Rev. 2008, 108, 4628-4669.

[72] I.W. Bauer, S-P. Li, Y-C. Han, L. Yuan, M-Z. Yin, J. Mater. Sci.: Mater. Med. 2008, 19,1091-1095 
[73] V. Sokolova, D. Kozlova, T. Knuschke, J. Buer, A.M. Westendorf, M. Epple. Acta Biomater. 2013, 9, 7527-7535

[74] E.H. Chowdhury, A. Maruyama, A. Kano, M. Nagaoka, M. Kotaka, S. Hirose, M. Kunou, T. Akaike, Gene 2006, 376, 87-94.

[75] H.G. Martinson, H.G., Biochemistry 1973, 12, 145-150.

[76] G. Bernardi, Nature 1965, 206, 770-783.

[77] T. Watanabea, K. Makitsurua, H. Nakazawa, S. Hara, T. Suehiro, A. Yamamoto, T. Hiraide, T. Ogawa, Anal. Chim. Acta 1999, 386, 69-75.

[78] M.J. Benton, Science, 1995, 268, 52-58.

[79] J.D. Watson, F. Crick, Nature, 1953, 171, 737-740. 
Entry for the Table of Contents (Please choose one layout)

Layout 1:

\section{CONCEPT}

Text for Table of Contents.

\section{Graphical frontispiece}

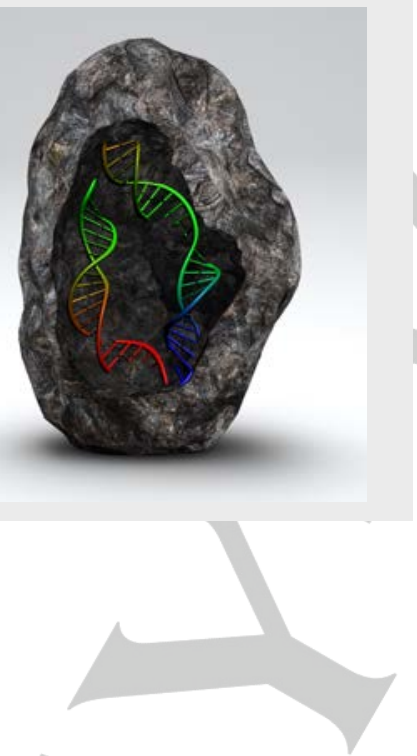

Pau Turon, * Jordi Puiggalí, * Oscar

Bertan, Carlos Alemán*

Page No. - Page No.

Surviving Mass Extinctions Through

Biomineralized DNA

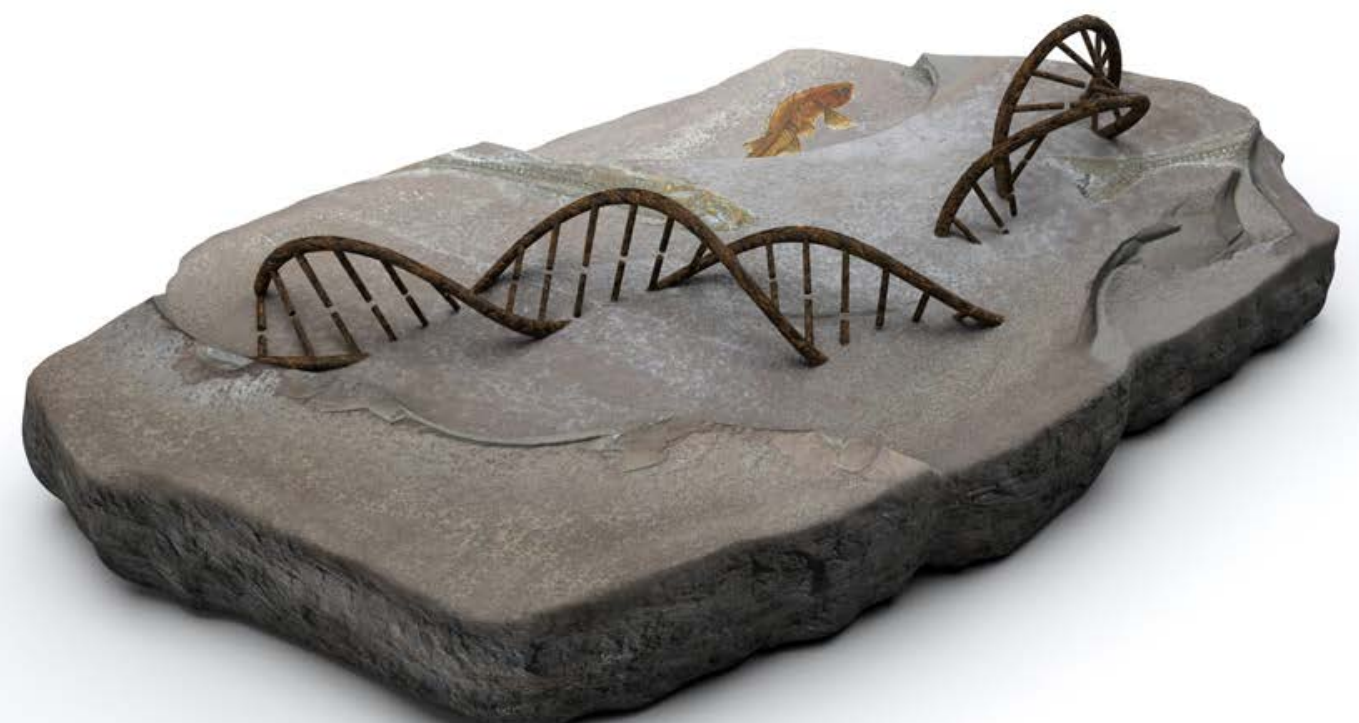

